\title{
Preparation and characterisation of tamarind 4-hydroxybenzoic acid (THBA) resin and its use in extraction of heavy metal ions from industrial wastewater
}

\author{
AV Singh* and Indraj Kumar Kumawat \\ Department of Chemistry, Jai Narain Vyas University, Jodhpur - 342033, Rajasthan, India
}

\begin{abstract}
The adsorption of heavy metal cations, $\mathrm{Pb}(\mathrm{II}), \mathrm{Cd}(\mathrm{II}), \mathrm{Cu}(\mathrm{II}), \mathrm{Zn}(\mathrm{II})$ and $\mathrm{Fe}(\mathrm{II})$ from aqueous solution by newly-synthesized tamarind 4-hydroxybenzoic acid (THBA) resin was investigated. The resin was characterised on the basis of FTIR, elemental analysis, ion-exchange capacity and physico-chemical properties. The distribution coefficients $\left(K_{d}\right)$ and percentage adsorption of metal ions on resin were determined by batch methods using atomic absorption spectrophotometry (AAS). The effect of experimental parameters, such as $\mathrm{pH}$, treatment time, temperature, adsorbent dose, initial metal ion concentration and flow rate, on the removal of metal ions was also studied. THBA resin proved to be an effective adsorbent for the removal of different heavy metal ions from aqueous solution; removal efficiency followed the order: $\mathrm{Fe}(\mathrm{II})>\mathrm{Cu}(\mathrm{II})>\mathrm{Zn}$ (II) $>\mathrm{Cd}(\mathrm{II})>\mathrm{Pb}(\mathrm{II})$. These results suggest that the cation exchange resin THBA holds great potential to remove cationic heavy metal species from industrial wastewater.
\end{abstract}

Keywords: batch method, distribution coefficient, ion-exchange capacity, FTIR spectra, THBA resin

\section{Introduction}

Toxic metals can be distinguished from other pollutants, since they are not biodegradable and can be accumulated in nature. They also cause various diseases and disorders when exceeding specific limits. An excess amount of heavy metal ions in aquatic environments is known to cause severe damage to human health and aquatic life. Therefore, separation of these metal ions from natural water at trace level is of paramount importance both for water purification and analysis. The complete removal of toxic heavy metal ions that are incompatible with biological systems requires expensive treatment in order to produce water that is again useful for domestic use (Monteagudo and Ortiz, 2000). It is essential to extend methods for removal of metal ions to decrease the pollution load on the environment. Classical techniques of heavy metal removal from solutions include the following processes: solvent extraction (Shukla and Rao, 2002), precipitation and coprecipitation (Kagaya et al., 2000), electrochemical reduction (Basha et al., 2008), chemical- and biosorption (Chang et al., 2002), pre-concentration (Ekic et al., 2004), reverse osmosis (Gibert et al., 2010) and ion exchange (Nabi and Naushad, 2008; Wong et al., 2007; Inamuddin et al., 2007; Khan and Alam, 2004).

In recent years, the adsorption process has also received much attention and has become one of the more popular methods for the removal of heavy metal ions from wastewater, because of its competitive and effective process. Numerous adsorbents have been reported for the removal of toxic metal ions, such as chitin (Santosa et al., 2007), chitosan (Wan Nagh et al., 2002), starch (Delval et al., 2005), cellulose

\footnotetext{
* To whom all correspondence should be addressed.

II +91 9461286995; fax: +91 0291 2720436; e-mail: areshvikram04@rediffmail.com

Received 10 August 2011; accepted in revised form 3 July 2012.
}

(El-Mensnawy et al., 2008; Gupta et al., 2002; Gerente et al., 2000; Zhou et al., 2004; Guclu et al., 2003), guaran (Singh et al., 1996), and cyclodextrin (Kozlowski et al., 2005), which are not only eco-friendly and cost-effective but are also effective in remediation of common effluents present in wastewater. Other polysaccharide-based materials and alumino-silicates are used as adsorbents in wastewater treatment (Crini, 2005; Aguiar et al., 2002; Rubio et al., 1997). Adsorption using commercial activated carbon (CAC) can remove metal ions from wastewater, such as $\mathrm{Cd}(\mathrm{II}), \mathrm{Ni}(\mathrm{II}), \mathrm{Cr}(\mathrm{III})$ and $\mathrm{Cu}(\mathrm{II})$ (Ramos et al., 1997; Shim et al., 2001; Ouki et al., 1999; Monser et al., 2002). However, CAC is an expensive material. Resins prepared with divinyl benzene-styrene backbone are hydrophobic (Sarin et al., 1980). These resins, prepared from petrochemicals, are costly. Their ion exchange capacity depends mainly on the quantity of functional groups and the $\mathrm{pH}$ of the solution. The most widespread chelating functional groups used for removal of metal ions from effluents are thiol (Saha et al., 2000), thiourea (Hubicki et al., 2009), dithionite (Grote et al., 2001), aspartate (Chuh-Yean et al., 2008) and triisobutyl phosphine sulphide (Hidalgo et al., 2001).

Tamarind kernel powder (TKP) is obtained from the seeds of the tamarind tree, Tamarindus indica, a common forest and cultivated tree found primarily in India, Burma, Bangladesh and Sri Lanka. TKP is a polymer with an average molecular weight of 52350 and a monomer containing 3 sugars, glucose, galactose, and xylose in a molar ratio of 3:1:2, was reported by Khanna and Sarin (1987). The polymer consists of a cellulosetype spine, which carries xylose and galactoxylose substituents. About $80 \%$ of the glucose residues are substituted by a $1+6$ linked xylose units, which themselves are partially substituted by 1-2 galactose residues (Lang et al., 1993). The structure of tamarind kernel powder is given in Fig. 1.

The ion exchanger based on tamarind kernel powder is hydrophilic and biodegradable, whereas ion exchangers prepared from petrochemical products are hydrophobic and not 


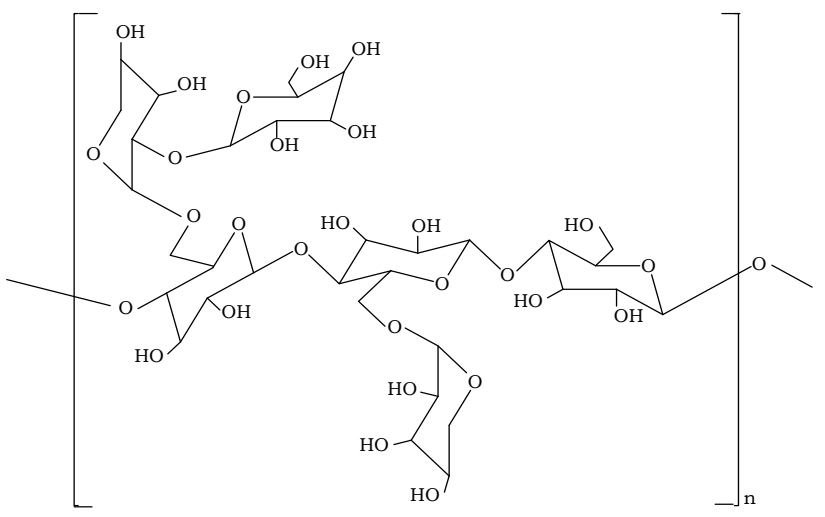

Figure 1

Structure of tamarind

biodegradable. Due to rising prices of petroleum products TKP has been selected for development of tamarind 4-hydroxybenzoic acid (THBA) resin. Its cost is low and it is locally available in large quantities from agricultural resources; such biopolymers are environmentally friendly.

The work reported herein was undertaken to study the synthesis and characterisation of THBA resin and its applications for removal and recovery of toxic metal ions from the effluent of Paradise Steel Industry, Jodhpur, India, in the form of batch and column processes. The influence of various factors affecting adsorption conditions, $\mathrm{pH}$, temperature, stirring time, treatment time and resin dose, on the removal of metal ions was studied.

\section{Materials and methods}

\section{Chemicals}

Analytical grade chemicals were used in all experiments. All compounds used in the synthesis were of commercial high purity grade. Tamarind kernel powder (Ases Chemical Works, Jodhpur, India), epichlorohydrin (British Drug Houses Ltd. Poole England), 4-hydroxybenzoic acid (Loba Chemic Pvt Ltd, Mumbai, India), sodium hydroxide (Sarabhai M. Chemicals, Baroda, India), dioxane (E Merk, Mumbai, India), methanol (Allied Chemical Corporation, Varodra, India), hydrochloric acid (CDH Pvt. Ltd, New Delhi). The standard solution (self-made) was a $1000 \mathrm{mg} / \mathrm{kg}$ solution of metal ions $\left(\mathrm{CuSO}_{4} \cdot 5 \mathrm{H}_{2} \mathrm{O},\left(\mathrm{NH}_{4}\right)_{2} \mathrm{Fe}\left(\mathrm{SO}_{4}\right)_{2} \cdot 6 \mathrm{H}_{2} \mathrm{O}, \mathrm{CdSO}_{4} \cdot \mathrm{H}_{2} \mathrm{O}, \mathrm{Pb}\left(\mathrm{NO}_{3}\right)_{2}\right.$, $\mathrm{ZnSO}_{4} \cdot 7 \mathrm{H}_{2} \mathrm{O}$ (Loba Chemic Pvt Ltd, Mumbai, India), which was then diluted to different solution concentrations. The characteristic features of the effluent of Paradise Steel Industry, Jodhpur (Rajasthan) are presented in Table 1.
Synthesis of tamarind 4-hydroxybenzoic acid (THBA) resin

Step A: Preparation of epoxypropyl ether of tamarind An amount of $182.2 \mathrm{~g}$ of tamarind kernel powder ( $0.2 \mathrm{~mol})$ was taken in a round-bottom flask and was slurried with dioxan. Subsequently, $15 \mathrm{~m} \ell$ of $40 \%$ (w/v) sodium hydroxide was added to make the solution alkaline, until the $\mathrm{pH}$ reached 8.5. The solution was stirred at $60^{\circ} \mathrm{C}$. Then $9.25 \mathrm{~g}(0.1 \mathrm{~mol})$ epoxychloropropane (epichlorohydrin) was added with constant stirring. The stirring was further continued for $5 \mathrm{~h}$, at $60^{\circ} \mathrm{C}$. The product, epoxypropyl ether of tamarind, was filtered under vacuum, washed with methanol to remove impurities, and dried (Singh et al., 2011).

\section{Step B: Preparation of tamarind 4-hydroxybenzoic acid (THBA) resin}

Epoxypropyl ether of tamarind, synthesized in Step A, was allowed to react with $13.8 \mathrm{~g}(0.1 \mathrm{~mol})$ of 4-hydroxybenzoic acid; the mixture was stirred for $5 \mathrm{~h}$ at $60^{\circ} \mathrm{C}$ and left overnight. The product was filtered under vacuum and washed with $90 \%$ methanol, which also contained a few drops of hydrochloric acid to remove inorganic impurities. Finally, it was washed with pure methanol. The product, tamarind 4-hydroxybenzoic acid (THBA) resin, was a free-flowing light yellow powder and the yield was $205.3 \mathrm{~g}$. The reaction scheme is shown in Fig. 2.

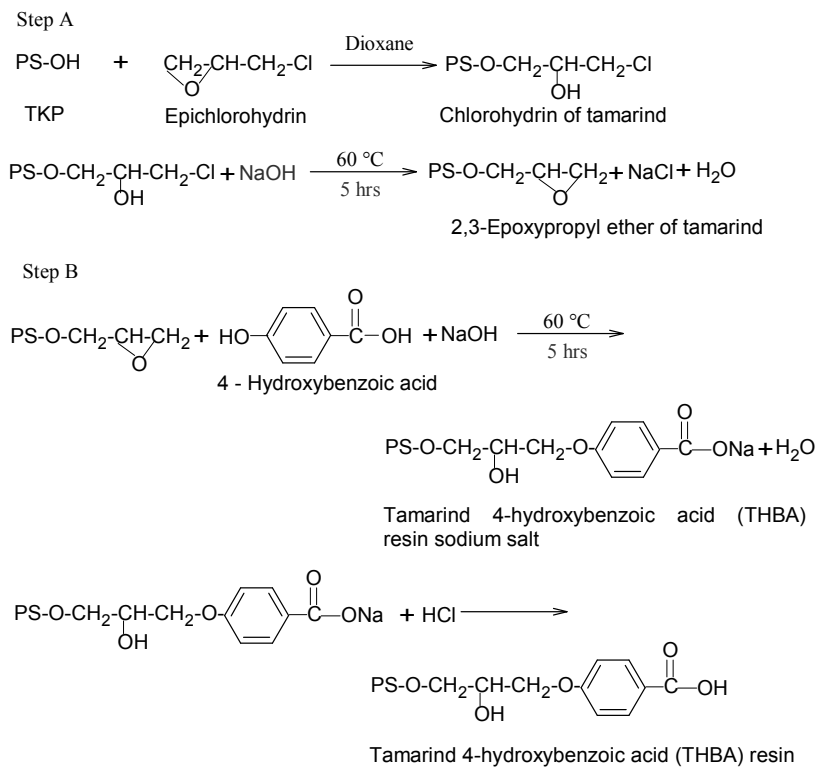

PS = Tamarind Kernel powder

Figure 2

Synthesis of tamarind 4-hydroxybenzoic acid (THBA) resin

Table 1

The characteristic features of effluent of Paradise Steel Industry, Jodhpur

Appearance: Turbid

Colour: Dirty brown

pH: 6.2

Total hardness: $850.9 \mathrm{mg} / \mathrm{kg}$

\begin{tabular}{|l|l|l|l|l|l|l|l|}
\hline Metal ion & $\mathrm{Fe}^{2+}$ & $\mathrm{Cu}^{2+}$ & $\mathrm{Zn}^{2+}$ & $\mathrm{Pb}^{2+}$ & $\mathrm{Cd}^{2+}$ & $\mathrm{Mg}^{2+}$ & $\mathrm{Ca}^{2+}$ \\
\hline Concentration (in ppm) & 1.12 & 0.52 & 5.18 & 0.69 & 0.18 & 102.6 & 172.9 \\
\hline
\end{tabular}

Other anions $(\mathrm{mg} / \mathrm{kg})$ : fluoride $=0.72 ;$ sulphate $=468 ;$ cyanide $=0.04$

Acceptable level of toxic metal ions in water $(\mathrm{mg} / \mathrm{kg})$ : $\mathrm{Fe}^{2+}=0.1, \mathrm{Cu}^{2+}=0.05, \mathrm{Zn}^{2+}=5.0, \mathrm{~Pb}^{2+}=0.1, \mathrm{Cd}^{2+}=0.1$ 


\section{Water washing of resin}

The resins were washed with diluted $\mathrm{HCl}$ to create the hydrogen form, and the hydrogen form of the resin was then washed with double-distilled water to remove all of the excess acid. The dried material at $378 \mathrm{~K}$ was used for further experimental work.

\section{Physico-chemical characteristics}

The physico-chemical properties, such as percentage moisture content, percentage solid, true density, apparent density, void volume fraction and volume capacity and ion exchange capacity were analysed according to standard methods (Vogel, 1989; Helfferich, 1962).The physico-chemical characteristics of the synthesised tamarind 4-hydroxybenzoic acid are summarised in Table 2.

\begin{tabular}{|l|l|}
\hline \multicolumn{2}{|c|}{$\begin{array}{c}\text { Pable } 2 \\
\text { Physico-chemical characteristics of the } \\
\text { synthesized tamarind 4-hydroxybenzoic acid resin }\end{array}$} \\
\hline Property & Value (SD) \\
\hline Active group & $-\mathrm{COOH}$ \\
\hline Ionic form as shipped & $\mathrm{H}^{+}$ \\
\hline$\%$ moisture & $13.7 \pm 0.5$ \\
\hline$\%$ solid & $86.3 \pm 0.5$ \\
\hline True density $\left(\mathrm{g} / \mathrm{cm}^{3}\right)$ & $1.31 \pm 0.02$ \\
\hline Apparent density $(\mathrm{g} / \mathrm{m} \ell)$ & $0.6632 \pm 0.0052$ \\
\hline Void volume fraction & $0.3571 \pm 0.1131$ \\
\hline Volume capacity $\left(\mathrm{mmol} / \mathrm{cm}^{3}\right)$ & $2.84 \pm 0.05$ \\
\hline Total exchange capacity $\left(\mathrm{meq}^{3} \mathrm{~g}\right)$ & 4.62 \\
\hline Particle size $(\mathrm{mm})$ & $0.26 \pm 0.05$ \\
\hline Thermal stability & $404^{0}$ \\
\hline Operating $\mathrm{pH}$ range & $1-7$ \\
\hline
\end{tabular}

\section{Batch experiment}

The distribution coefficients (Kd) and percentage adsorption of metal ions on resin were determined using the batch method. The $\mathrm{pH}$ of solution was adjusted by a suitable buffer at desired values: $\mathrm{KC1}-\mathrm{HCl}$ buffer for $\mathrm{pH} 1$ to 2; acetate buffer for $\mathrm{pH} 3$ to 7 . A sample solution (100 $\mathrm{m} \ell$ ) containing a known concentration of the studied metal ion was transferred to an Erlenmeyer flask and, after adjusting the $\mathrm{pH}$, $100 \mathrm{mg}$ of the modified THBA resin was added to the solution, the mixture was shaken continuously in a temperaturecontrolled shaker at $25 \pm 2^{\circ} \mathrm{C}$ for $4 \mathrm{~h}$ and the contents were equilibrated. The solution was filtered through Whatman filter paper no. 40 . The residue on the filter paper was equilibrated with $0.1-2.0 \mathrm{~mol} / \mathrm{m}^{3} \mathrm{HCl}$ and the solution was filtered through Whatman filter paper no. 42.

The toxic metal ion concentration in the filtrate as well as in the residue was estimated using a Perkin-Elmer model 2380 atomic absorption spectrophotometer. The calibration curves for different metal ions were plotted, by analysing a series of standard solutions of metal ions using AAS. The flame type was air-acetylene and absorption wavelengths were $\mathrm{Zn}^{2+}(213.6 \mathrm{~nm}), \mathrm{Fe}^{2+}(324.8 \mathrm{~nm}), \mathrm{Cu}^{2+}(324.8 \mathrm{~nm}) \mathrm{Cd}^{2+}$ $(228.8 \mathrm{~nm})$ and $\mathrm{Pb}^{2+}(283.2 \mathrm{~nm})$. The concentration of metal ion in the filtrate was determined by the calibration curves. The distribution coefficient $\left(K_{d}\right)$ and percentage adsorption of the metal ions on THBA resin were calculated using the equations:

$$
K_{d}=\frac{\text { Amount of metal ion in resin phase }}{\text { Amount of metal ion in solution phase }} \times \frac{V}{m} \mathrm{~m} \ell / \mathrm{g}
$$

where:

$V$ is the volume of the solution $(\mathrm{m} \ell)$

$m$ is the weight of the dry resin $(\mathrm{g})$

Percentage adsorption of metal ions $=\frac{C_{i}-C_{f}}{C_{f}} \times 100$

where:

$C_{i}$ is the initial concentration of metal ion in solution and

$C_{f}$ is the final amount of metal ion in solution after equilibrium with resin.

\section{Column experiment}

In the column experiment, a glass tube with $1.6 \mathrm{~cm}$ internal diameter and $20 \mathrm{~cm}$ height, packed with $8 \mathrm{~cm}$ of resin $(7.0 \mathrm{~g})$, was used. $50 \mathrm{~m} \ell$ of the sample metal ion solution was passed through the column at a flow rate of $2 \mathrm{~m} \ell / \mathrm{min}$. The flow rate was controlled by a peristaltic pump. The column was washed with $20 \mathrm{~m} \ell$ of deionised water and the washing was rejected. The metal ions were eluted quantitatively with different strengths of acids.

\section{Ion exchange capacity (IEC) determination}

Resin capacity is usually expressed in terms of equivalents per litre $(\mathrm{eq} / \ell)$ of resin or milli-equivalents per dry gram of resin. The ion exchange capacity, which is generally taken as a measure of the hydrogen ion liberated by a neutral salt flowing through the composite cation exchanger, was determined by a standard column process. $0.1 \mathrm{~g}$ (dry mass) of the composite ion exchange material in $\mathrm{H}^{+}$form was placed in a glass column with a glass wool support at the bottom. It was washed with demineralised water to remove any excess acid that remained on the particles. The hydrogen ions were eluted with $0.1 \mathrm{M}$ solution of different alkali and alkaline earth salts. The flow rate was kept at $4 \mathrm{~m} \ell / \mathrm{min}$. The collected effluent was titrated against a standard solution of sodium hydroxide using phenolphthalein as an indicator. The hydrogen ions released were then calculated according to the method described by Vogel (1989) and was found to be $4.62 \mathrm{meq} / \mathrm{g}$.

\section{Results and discussion}

\section{Fourier transform infrared spectroscopy (FTIR) characterisation of tamarind 4-hydroxybenzoic acid (THBA) resin}

A Varian model 640 FTIR instrument was employed for the FTIR spectral analysis of synthesized THBA resin using $\mathrm{KBr}$ pellets. The FTIR spectrum of tamarind powder shows a broad band in the region $3600-3200 \mathrm{~cm}^{-1}$ characteristic of $-\mathrm{OH}$ stretching. The peak at $2936 \mathrm{~cm}^{-1}$ is attributed to $\mathrm{C}-\mathrm{H}$ stretching vibrations; a strong and sharp peak at $1650 \mathrm{~cm}^{-1}$ is due to $\mathrm{O}-\mathrm{H}$ bending and the variable peak at $1480-1350 \mathrm{~cm}^{-1}$ is attributed to $\mathrm{C}-\mathrm{H}$ bending. A strong peak at $1300-1000$ $\mathrm{cm}^{-1}$ denotes $\mathrm{C}-\mathrm{O}$ stretching vibration. The FTIR spectrum of tamarind is shown in Fig. 3.

The FTIR spectrum of THBA resin shows a peak at 3100 $-3000 \mathrm{~cm}^{-1}$ which is attributed to $\mathrm{C}-\mathrm{H}$ stretching vibration in aromatic nuclei. A strong peak in the region $1250-1000 \mathrm{~cm}^{-1}$ denotes $\mathrm{C}-\mathrm{O}$ stretching vibrations. The peak at $1700-1680$ 


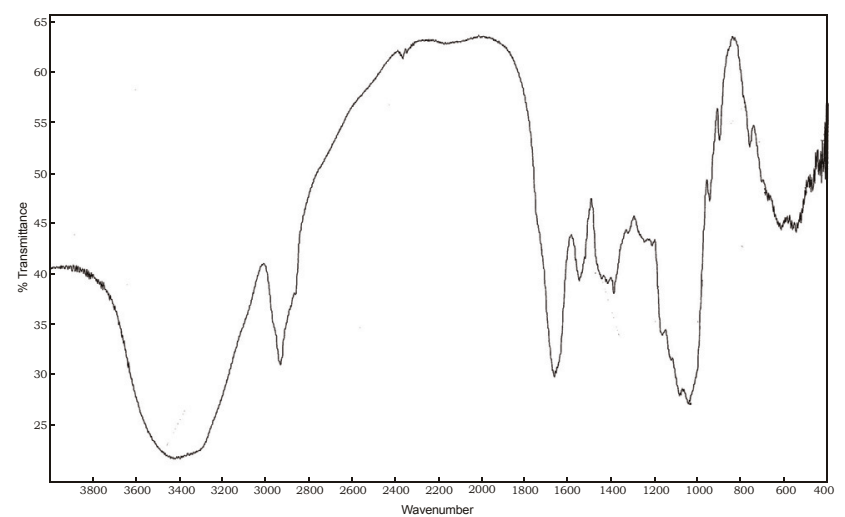

Figure 3

FTIR spectrum of tamarind kernel powder

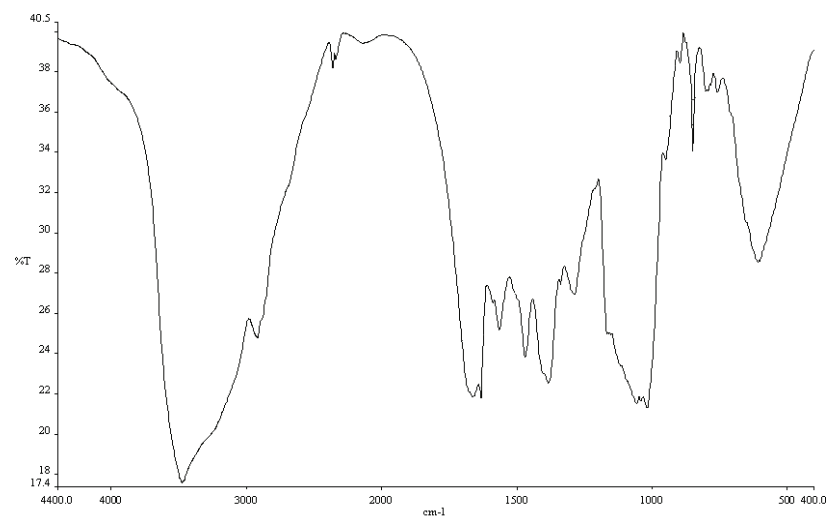

Figure 4

FTIR spectrum of tamarind 4-hydroxybenzoic acid (THBA) resin

Table 3

\begin{tabular}{|c|c|c|c|c|c|}
\hline $\mathrm{pH}$ & $\mathrm{Fo}^{2+}$ & & $\mathrm{S}^{2+2+}$ & 2017 & \\
\hline 1 & 1963 & 1106 & 534 & 620 & 1255 \\
\hline 2 & 31.66 & 16.85 & 7.68 & 11.02 & 19.35 \\
\hline 3 & 72.65 & 73.81 & 16.75 & 15.16 & 32.32 \\
\hline 4 & 219.91 & 130.87 & 40.09 & 34.39 & 54.73 \\
\hline 5 & 56.86 & 43.57 & 83.71 & 51.18 & 100.89 \\
\hline 6 & 15.71 & 15.92 & 164.58 & 73.78 & 45.05 \\
\hline 7 & 8.43 & 13.04 & 14.86 & 17.22 & 17.80 \\
\hline
\end{tabular}

metal ions on the THBA resin increases with $\mathrm{pH}$ and reaches its maximum value at $\mathrm{pH} 4-6$, declining at higher $\mathrm{pH}$. It has been found that the maximum removal percentages for $\mathrm{Fe}(\mathrm{II})$, $\mathrm{Cu}(\mathrm{II}), \mathrm{Zn}(\mathrm{II}), \mathrm{Pb}(\mathrm{II})$ and $\mathrm{Cd}(\mathrm{II})$ are $95.65 \%, 94.27 \%, 92.90 \%$, $90.98 \%$ and $87.74 \%$, respectively.

It is clear from Table 4 that the percentage removal of metal ions first increases and then decreases with increasing $\mathrm{pH}$. Similar results have been reported for a previous study with amberlite IR-120 (Demirbas et al., 2004). This suggests that selectivity of the metal ion is dependent on $\mathrm{pH}$. The maximum removal of toxic metal ions is obtained when a strong electric field is present and the electrostatic effect may become the dominant factor, such that small ions, which have a huge charge density, are bound more strongly with the resin (Gode and Pehlivan, 2005). In an acidic medium, the $\mathrm{H}^{+}$ions of the THBA resin easily exchange with metal ions. starts when the $\mathrm{pH}$ rises to the range where most acidic ion exchange sites start to exchange hydronium ions for metal ions, and the capacity reaches the maximum value in the $\mathrm{pH}$ range where all the ion exchange sites take part in the reaction and the functional group is able to form complexes with the metal cations (Nenov and Bonev, 2010). The decrease in $K_{d}$ values after the maximum in the neutral and alkaline region can be explained by the complex formation of THBA resin with heavy metal ions. High values of the distribution coefficient indicate that the metal has been retained by the resin through adsorption, while low values of $K_{d}$ indicate that a large fraction of the metal remain in solution.

\section{Removal of metal ions from effluent of Paradise Steel Industry, Jodhpur, by THBA Resin}

The results for percentage removal of metal ions from effluent of Paradise Steel Industry, Jodhpur, by THBA resin are summarised in Table 4. The adsorption percentage for the

\begin{tabular}{|c|c|c|c|c|c|}
\hline \multicolumn{7}{|c|}{$\begin{array}{c}\text { Table 4 } \\
\text { Percentage removal of metal ions from effluent of } \\
\text { Paradise Steel Industry, Jodhpur, by THBA resin }\end{array}$} \\
\hline $\mathbf{p H}$ & $\mathbf{F e}^{2+}$ & $\mathbf{Z n}^{2+}$ & $\mathbf{C u}^{2+}$ & $\mathbf{C d}^{2+}$ & $\mathbf{P b}^{2+}$ \\
\hline 1 & 66.25 & 52.73 & 34.71 & 38.27 & 55.66 \\
\hline 2 & 76.00 & 62.76 & 43.44 & 52.41 & 65.93 \\
\hline 3 & 87.90 & 88.06 & 62.62 & 60.26 & 76.37 \\
\hline 4 & $\mathbf{9 5 . 6 5}$ & $\mathbf{9 2 . 9 0}$ & 80.03 & 77.47 & 84.55 \\
\hline 5 & 85.08 & 81.33 & 89.32 & 83.65 & $\mathbf{9 0 . 9 8}$ \\
\hline 6 & 61.11 & 61.41 & $\mathbf{9 4 . 2 7}$ & $\mathbf{8 7 . 7 4}$ & 81.33 \\
\hline 7 & 45.71 & 56.60 & 59.78 & 63.92 & 64.40 \\
\hline
\end{tabular}

\section{Mechanisms for adsorption of metal ions on THBA resin}

The heavy metal ions' adsorption onto the surface of the THBA resin is assumed to occur through ion-exchange and 


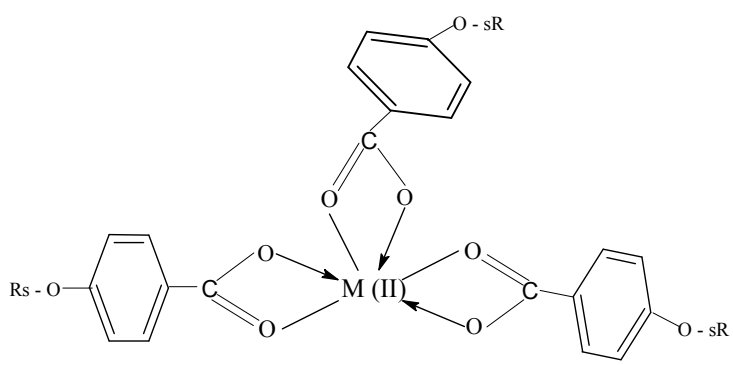

Octahedral complex of THBA resin with metal ions<smiles>[R2]OC1=CC=C2C=CC3=C1[Al](OC2=O)O[Al]3OC(=O)c1ccc(O[R2])cc1</smiles>

Tetrahedral complex of THBA resin with metal ion

Rs $=$ Resin matrix

Figure 5

Complex structure of THBA resin

chelation between charged heavy metal ions and ionised carboxylic groups, which is depicted in the following equation:

$$
\mathrm{nR}-\mathrm{COOH}+\mathrm{Me}^{\mathrm{n}+} \rightarrow(\mathrm{R}-\mathrm{COO})_{\mathrm{n}}^{-} \mathrm{Me}^{\mathrm{n}+}+\mathrm{nH}^{+}
$$

Hydrogen ions in the carboxylic group $(-\mathrm{COOH})$ of the resin can serve as exchangeable ions with metal cations. The THBA resin has many carboxyl ions $(-\mathrm{COOH})$, which can serve as the adsorption sites for ion exchange and chelation. In an aqueous solution these groups within the resin dissociate to yield protons, leading to a decrease in solution $\mathrm{pH}$. This is testified to by the $\mathrm{pH}$ variation of the suspension before and after adsorption, as stated above. This suggests that, along with the shift or disappearance of some characteristic group, chelation occurs between the adsorbent and adsorbate. In consideration of this, it can be deduced that ion exchange and chelation coexists during the entire adsorption process. The complex structure of THBA resin is given in Fig. 5.

\section{Statistical analysis}

The relative standard deviation values (RSD) of optimum removal percentages for the metal ions are shown in Table 5. All data represent the mean of the results of 3 independent experiments. The results revealed that the relative standard deviation (RSD) of the method was lower than 3.0, which indicated that the method had good precision for the analysis of trace metal ions in solution samples.

\begin{tabular}{|c|c|c|c|c|}
\hline \multicolumn{5}{|c|}{$\begin{array}{c}\text { Table } 5 \\
\text { Optimum results for the removal of metal ions from the } \\
\text { effluent of Paradise Steel Industry, Jodhpur, on THBA } \\
\text { resin }\end{array}$} \\
\hline $\begin{array}{l}\text { Metal } \\
\text { ions }\end{array}$ & $\begin{array}{l}\text { Amount of } \\
\text { metal ions } \\
\text { in effluent } \\
\quad(\mathrm{mg})\end{array}$ & $\begin{array}{c}\text { Amount } \\
\text { loaded } \\
\text { on THBA } \\
\text { resin }(\mathrm{mg})\end{array}$ & $\begin{array}{c}\text { Removal } \\
\text { percentage }\end{array}$ & RSD \% \\
\hline $\mathrm{Fe}^{2+}$ & 1.12 & 1.071 & 95.65 & 1.62 \\
\hline $\mathbf{C u}^{2+}$ & 0.52 & 0.492 & 94.27 & 1.32 \\
\hline $\mathbf{Z n}^{2+}$ & 5.18 & 4.812 & 94.27 & 1.46 \\
\hline $\mathbf{P b}^{2+}$ & 0.692 & 0.629 & 90.98 & 2.64 \\
\hline $\mathbf{C d}^{2+}$ & 0.186 & 0.163 & 87.74 & 2.16 \\
\hline
\end{tabular}

\section{Use of eluent and recovery of metal ions}

The recovery of metal ions was determined in the column experiment. In the column experiment the metal ions were eluted quantitatively with different strengths of acid. The $\mathrm{Cd}$ (II) was eluted with $0.1 \mathrm{~mol} / \mathrm{m}^{3} \mathrm{HCl}, \mathrm{Pb}(\mathrm{II})$ with $0.5 \mathrm{~mol} / \mathrm{m}^{3}$ $\mathrm{HCl}, \mathrm{Zn}(\mathrm{II})$ with $1.0 \mathrm{~mol} / \mathrm{m}^{3} \mathrm{HCl}, \mathrm{Cu}(\mathrm{II})$ with $1.5 \mathrm{~mol} / \mathrm{m}^{3} \mathrm{HCl}$ and $\mathrm{Fe}(\mathrm{II})$ was eluted with $2.0 \mathrm{~mol} / \mathrm{m}^{3} \mathrm{HCl}$. The resin column was then washed thoroughly with demineralised water. The amounts of metal ions in the filtrate solution were analysed using AAS. Recoveries of $\mathrm{Cd}(\mathrm{II}), \mathrm{Pb}(\mathrm{II}), \mathrm{Zn}(\mathrm{II}), \mathrm{Cu}(\mathrm{II})$ and $\mathrm{Fe}(\mathrm{II})$ were determined as $96.31 \%, 96.66 \%, 97.36 \%, 98.17 \%$ and $99.06 \%$, respectively. The elution of metal ions was carried out with hydrochloric acid solution, using the advantage that the chloride ion is an acceptable matrix for both AAS and spectrophotometric determination of metal ions. Data presented in Table 6 indicate that different quantities and strengths of hydrochloric acid solution could afford quantitative elution of different metal ions from the resin. Dev and Rao (1996) used modified Amberlite XAD-4 with bis-(N,N- Salicylidene)1,3-propanediamine for the separation of $\mathrm{Ni}(\mathrm{II}), \mathrm{Fe}(\mathrm{II}), \mathrm{Ni}(\mathrm{II})$, $\mathrm{Co}(\mathrm{II}), \mathrm{Zn}(\mathrm{II}), \mathrm{Hg}(\mathrm{II}), \mathrm{Pb}(\mathrm{II})$, and sorbed metals were eluted by $1 \mathrm{M} \mathrm{HCl}$ with about $100 \%$ recovery. The recoveries of metal ions by elution were calculated according to Eq. (4).

Recovery $\%=\frac{\text { Amount of metal ions desorbed to the elution medium }}{\text { Amount of metal cations adsorbed on the resin }} \times 100$ (4)

\begin{tabular}{|l|c|c|c|c|c|}
\hline \multicolumn{6}{|c|}{ Table 6 } \\
\hline \multicolumn{2}{|c|}{ Quantitative separation of metal ions on THBA column } \\
\hline $\begin{array}{l}\text { Metal } \\
\text { ion }\end{array}$ & $\begin{array}{c}\text { Amount } \\
\text { loaded } \\
\text { (mg) }\end{array}$ & $\begin{array}{c}\text { Amount } \\
\text { found } \\
\text { (mg) }\end{array}$ & $\begin{array}{c}\text { Recovery } \\
\text { percent- } \\
\text { age }\end{array}$ & $\begin{array}{c}\text { Eluent } \\
\text { HCl } \\
\left(\mathbf{m o l} / \mathbf{m}^{3}\right)\end{array}$ & $\begin{array}{c}\text { Eluent } \\
\text { volume } \\
\text { (me) }\end{array}$ \\
\hline $\mathbf{F e}^{2+}$ & 1.071 & 1.061 & 99.06 & 2.0 & 60 \\
\hline $\mathbf{C u}^{2+}$ & 0.492 & 0.483 & 98.17 & 1.5 & 55 \\
\hline $\mathbf{Z n}^{2+}$ & 4.812 & 4.685 & 97.36 & 1.0 & 50 \\
\hline $\mathbf{P b}^{2+}$ & 0.629 & 0.608 & 96.66 & 0.5 & 45 \\
\hline $\mathbf{C d}^{2+}$ & 0.163 & 0.157 & 96.31 & 0.1 & 40 \\
\hline
\end{tabular}

\section{Column reusability}

It was observed that the adsorbency of different metal ions on the THBA resin after 10 cycles (adsorption and desorption), and the ion exchange capacities of the resin were almost constant. The adsorbed metal ions were easily desorbed by treatment with different strengths of acid, at room temperature. Table 7 shows the adsorbency of different metal ions on the THBA resin after 10 cycles (adsorption and desorption).

\begin{tabular}{|c|c|c|c|c|c|}
\hline \multicolumn{6}{|c|}{$\begin{array}{c}\text { Table } 7 \\
\text { The adsorption percentage for different metal ions on } \\
\text { THBA resin (adsorption and desorption) }\end{array}$} \\
\hline \multirow[t]{2}{*}{$\begin{array}{l}\text { Metal } \\
\text { ions }\end{array}$} & \multicolumn{5}{|c|}{$\begin{array}{l}\text { Adsorption percentage for different } \\
\text { metal ions on THBA resin after } \\
\text { a number of cycles }\end{array}$} \\
\hline & 1 cycle & 2 cycles & 4 cycles & 8 cycles & 10 cycles \\
\hline $\mathbf{F e}^{2+}$ & 95.65 & 93.54 & 93.46 & 93.45 & 93.45 \\
\hline $\mathbf{C u}^{2+}$ & 94.27 & 92.21 & 92.14 & 92.13 & 92.13 \\
\hline $\mathbf{Z n}^{2+}$ & 92.90 & 90.68 & 90.42 & 90.41 & 90.40 \\
\hline $\mathbf{P b}^{2+}$ & 90.98 & 88.78 & 88.64 & 88.63 & 88.62 \\
\hline $\mathbf{C d}^{2+}$ & 87.74 & 85.58 & 85.44 & 85.42 & 96.42 \\
\hline
\end{tabular}




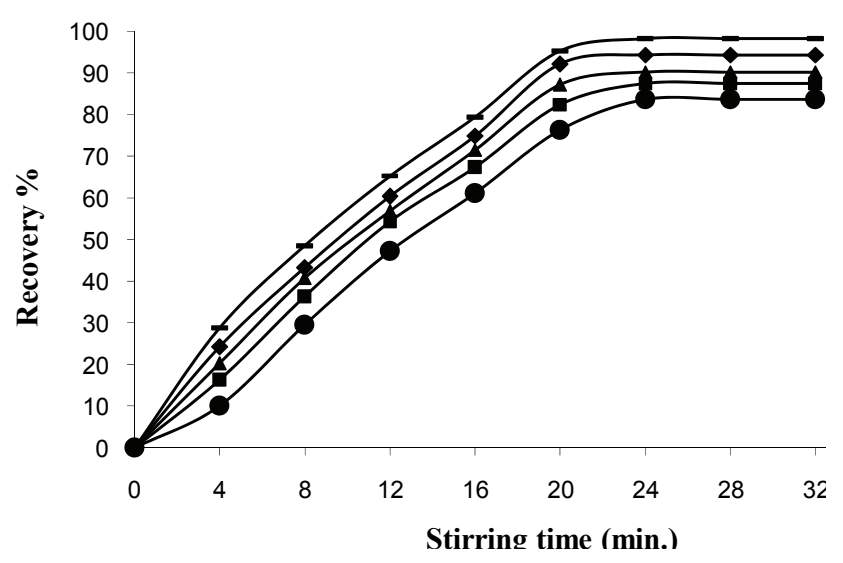

Figure 6

Effect of stirring time on the recovery of metal ions

\section{Effect of stirring time on the recovery of metal ions}

To determine the rate of sorption of metal ions on the THBA resin, batch experiments were elaborated by shaking the solution containing the ion with $100 \mathrm{mg}$ of the THBA resin at room temperature $\left(25^{\circ} \mathrm{C}\right)$. Aliquots of $1.0 \mathrm{~m} \ell$ solution were taken for analysis at pre-determined intervals. The concentration of metal ion in the supernatant solution was determined and the amount of metal ion sorbed on the THBA resin was calculated by mass balance. The sorption half-time $\left(t_{1 / 2}\right)$, defined as the time needed to reach $50 \%$ of the total sorption capacity, was estimated from Fig. 6. From the data obtained it was observed that the maximum sorption of metal ions with THBA resin reached its equilibrium time after about $24 \mathrm{~min}$. However, the time required for $50 \%$ sorption of metal ions was $11 \mathrm{~min}$ for THBA resin.

\section{Effect of pH}

The $\mathrm{pH}$ is an important parameter for adsorption of metal ions from aqueous solution because it affects the solubility of the metal ions, concentration of the counter ions on the functional groups of the adsorbent and the degree of ionisation of the adsorbent during reaction. To examine the variation of adsorption percentage for metal ions with $\mathrm{pH}$, the $\mathrm{pH}$ was varied from 1.0 to 7.0 as given in Table 4 . The uptake of free metal ions depends on $\mathrm{pH}$, where optimum adsorption of metal ions occurs at different $\mathrm{pHs}$ (ranging from 4 to 6 ), and then declines at higher $\mathrm{pH}$. Adsorption of metal ions on THBA resin increased over a $\mathrm{pH}$ range from 1.0 to 6.0, then decreased. At lower $\mathrm{pH}$ (acidic $\mathrm{pH}$ ), the adsorbent surface will be completely covered with hydronium ions which compete strongly with metal ions for adsorption sites. With an increase in $\mathrm{pH}$, the concentration of $\mathrm{H}_{3} \mathrm{O}^{+}$ions decreases, facilitating the adsorption of metal ions by the adsorbent (Radovic et al., 1997).

\section{Effect of contact time}

Treatment time indicates that the adsorption percentage for metal ions increased with an increase in contact time before equilibrium is reached. It is clear from Fig. 7 that adsorption of metal ions on THBA resin increased when contact time was increased from 30 to $210 \mathrm{~min}$; optimum contact time for THBA adsorbent was found to be $210 \mathrm{~min}$. Other parameters, such as $\mathrm{pH}$ of solution and agitation speed, were kept optimum,

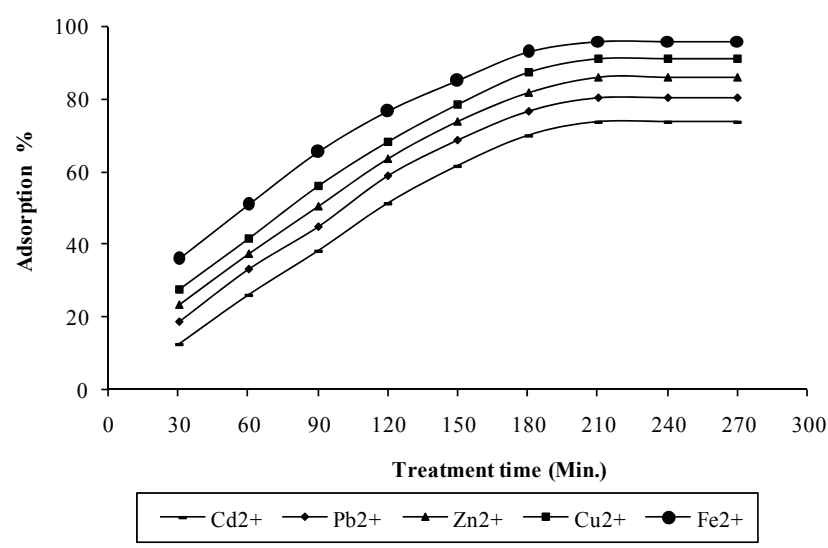

Figure 7

Effect of changing treatment time on the percentage adsorption of different metal ions on THBA resin

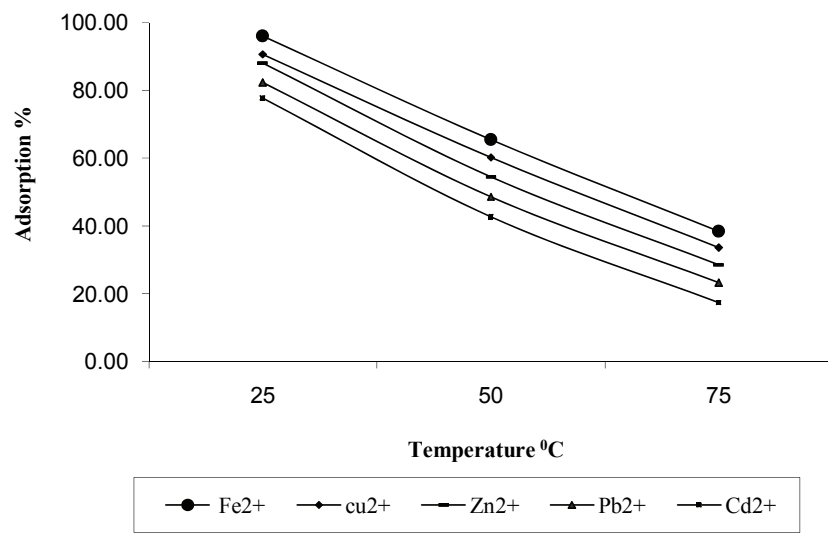

Figure 8

Effect of changing treatment temperature on the percentage adsorption of different metal ions on THBA resin

while temperature was kept at $25^{\circ} \mathrm{C}$. Greater availability of carboxylic and ether functional groups on the surface of TKP, which are required for interaction with metal ions, significantly improved the binding capacity and the process proceeded rapidly. This result is important, as equilibrium time is one of the important parameters for an economical wastewater treatment system.

\section{Effect of treatment temperature}

The effect of temperature on the adsorption percentage for metal ions onto THBA resin was studied. Figure 8 shows the effect of treatment temperature. The percentage adsorption of metal ions decreases by increasing the treatment temperature from $25^{\circ} \mathrm{C}$ to $50^{\circ} \mathrm{C}$ and then $75^{\circ} \mathrm{C}$, at the optimum treatment time of $4 \mathrm{~h}$. The working capacity of an ion exchanger depends on metal concentrations and temperatures. This observation is in full agreement with results published by Khalil et al. (1998).

\section{Effect of THBA dose on adsorption of metal ions}

The resin amount is also an important parameter influencing the quantitative adsorption of metal ions. The retention of the metal ions was examined in relation to the amount of resin used, in the range of $20-160 \mathrm{mg}$ and equilibrated for $4 \mathrm{~h}$. It is apparent that by increasing the resin amount, the adsorption 


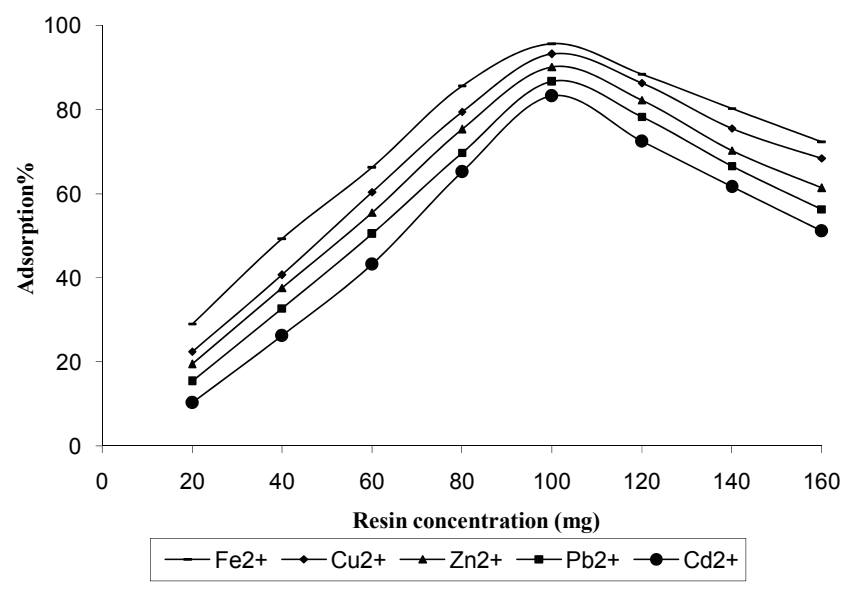

Figure 9

Effect of adsorbent dose on adsorption of metal ions on THBA resin

density and the amount of metal ions adsorbed per unit mass increases. The maximum adsorption by THBA resin was achieved with an adsorbent dose of $100 \mathrm{mg}$ and continued decreasing up to $160 \mathrm{mg}$. The initial increase in adsorption percentage for the metal ions was due to the greater surface area and increased number of adsorption sites available (Rengaraj et al., 2008). On increasing the THBA resin concentration further, the binding of metal ions steadily decreased. This effect might be attributed to overlapping or aggregation of adsorption sites of resin resulting in a decrease in the total surface area of the adsorbent. The results are shown in Fig. 9.

\section{Conclusions}

The removal of $\mathrm{Fe}(\mathrm{II}), \mathrm{Cu}(\mathrm{II}), \mathrm{Zn}(\mathrm{II}), \mathrm{Pb}(\mathrm{II})$ and $\mathrm{Cd}(\mathrm{II})$ ions by THBA resin is considered to be a very promising technique, due to its cost effectiveness, environmental friendliness, and short duration. The optimum conditions for removal of $\mathrm{Fe}(\mathrm{II})$, $\mathrm{Cu}(\mathrm{II}), \mathrm{Zn}(\mathrm{II}), \mathrm{Cd}(\mathrm{II})$ and $\mathrm{Pb}(\mathrm{II})$ ions using THBA cation exchange resin were found to be $\mathrm{pH} 4-6$ and stirring time $\sim 25 \mathrm{~min}$. A concentration of $0.1-2.00 \mathrm{~mol} / \mathrm{m}^{3} \mathrm{HCl}$ as eluent was sufficient to obtain maximum recovery for all metal ions. The relative standard deviations (RSD) for all of the experiments, indicating their repeatability and reproducibility were less than $3.0 \%$. These results indicate that the present method can be used for quantitative analyses and removal of toxic metal ions. The exchange bed could be used for more than 10 cycles with little loss of exchange capacity. The selectivity and ionexchange capacity of these materials towards metals ions can be controlled by the $\mathrm{pH}$ of the medium, stirring time, contact time, temperature, adsorbent dose, etc. Therefore the THBA resin is applicable for the removal and recovery of heavy metal ions from industrial effluents.

\section{Acknowledgments}

The authors are thankful to the Head, Department of Chemistry, J.N.V. University, Jodhpur, for providing all necessary facilities.

\section{References}

AGUIAR MRMP, NOVAES AC and GUARINO AWS (2002) Removal of heavy metals from wastewaters by aluminosilicate. Quim. Nova. 25 (6) 1145
BASHA CA, BHADRINARAYANA NS, ANANTHARAMAN N, MEERA SA and BEGUM KM (2008) Heavy metal removal from copper smelting effluent using electrochemical cylindrical flow reactor. J. Hazard. Mater. 152 (1) 71-78.

CHANG X, SU Q, LIANG D, WEI X and WANG B (2002) Efficiency and application of poly(acryldinitrophenylamidrazonedinitroacryl phenylhydrazine) chelating fiber for pre-concentrating and separating trace $\mathrm{Au}(\mathrm{III}), \mathrm{Ru}(\mathrm{III}), \mathrm{In}(\mathrm{III}), \mathrm{Bi}(\mathrm{III}), \mathrm{Zr}(\mathrm{IV}), \mathrm{V}(\mathrm{V}), \mathrm{Ga}(\mathrm{III})$ and Ti(IV) from solution samples. Talanta 57 (2) 253-261.

CRINI G (2005) Recent developments in polysaccharide based materials used as adsorbents in waste water treatment. Prog. Poly. Sci. 30 (1) $38-70$.

DELVAL F, CRINI G, BERTINI S, FILIATRE C and TORRI G (2005) Preparation, characterization and sorption properties of crosslinked starch-based exchangers. Carbohydr. Polym. 60 (1) $67-75$.

DEMIRBAS A, PEHLIVAN E, GODE F, ALTUN T and ARSLAN $\mathrm{G}$ (2004) Adsorption of $\mathrm{Cu}(\mathrm{II}), \mathrm{Zn}(\mathrm{II}), \mathrm{Ni}(\mathrm{II}), \mathrm{Pb}(\mathrm{II})$, and $\mathrm{Cd}(\mathrm{II})$ from aqueous solution on Amberlite IR-120 synthetic resin. J. Coll. Interf. Sci. 282 20-25.

DEV K and RAO GN (1996) Synthesis and analytical properties of a chelating resin functionalized with bis-( $N, N^{\prime}$-salicylidene) 1 , 3-propanediamine ligands. Talanta 43 (3) 451-457.

EKIC SD, FILIK H and APAK R (2004) Use of an o-aminobenzoic acid-functionalized XAD-4 Copolymer Resin for the separation and preconcentration of heavy metal(II) ions. Anal. Chim. Acta. 505 (1) $15-24$.

EL-MENSNAWY M, SALAMA A and EL-ASMY AA (2008) New modified cellulose for separation and determination of mercury in environment water sample. Can. J. Anal. Sci. Spectrom. 53 (5) 206-213.

GERENTE C, MENSIL PC, ANDRES Y, THIBAULT J and CLOIREC PL (2000) Removal of metal ions from aqueous solution on low cost natural polysaccharides: sorption mechanism approach. React. Funct. Polym. 46 (2) 135-144.

GIBERT O, VALDERRAMA C, PETERKÓVA M and CORTINA JL (2010) Evaluation of selective sorbents for the extraction of valuable metal ions $(\mathrm{Cs}, \mathrm{Rb}, \mathrm{Li}, \mathrm{U})$ from reverse osmosis rejected brine. Solv. Extr. Ion Exch. 28 (3) 543-562.

GODE F and PEHLIVAN EJ (2005) Removal of Cr(VI) from aqueous solution by two lewatit- anion exchange resins. J. Hazard. Mater. B. 119 175-182.

GROTE M and KETTRUP A (2001) Ion-exchange resins containing S-bonded dithizone and dehydrodithizone as functional groups: Part 1. Preparation of the resins and investigation of the sorption of noble metals and base metals. Anal. Chim. Acta. 172 223-239.

GUCLU G, GURDA G and OZGUMUS S (2003) Competitive removal of heavy metal ions by cellulose graft copolymers. J. Appl. Polym. Sci. 90 (8) 2034-2039.

GUPTA SC, DASS P, SHARMA P and SINGH AV (2002) Removal of $58 \mathrm{Co}, 134 \mathrm{Cs}$, and $95 \mathrm{Zr}$ radioisotopes from aqueous solutions using cellulose iminodiacetic acid chelating cum cation-exchanger. Desalination 143 (2) 141-145.

HELFFERICH F (1962) Ion Exchange. McGraw-Hill, New York. HIDALGO M, MASANA A, SALVADO V, MUNOZ M and VALIENTE M (2001) Extraction of palladium with tri-isobutylphosphine sulphide (cyanex 471) in toluene from chloride solutions containing thiocyanate. Talanta 38 483-488.

HUBICKI Z and LESZCZYNSK A (2009) Studies of the sorption of palladium (II) ions from model chloride systems onto an ion exchanger containing isothiourea groups and onto weakly basic anion exchangers of various types. Adsorption Sci. Technol. 22 603-614.

INAMUDDIN SA, SIDDIQUI WA and KHAN AA (2007) Synthesis, characterization and ion-exchange properties of a new and novel 'organic-inorganic' hybrid cation-exchanger: Nylon-6, 6, Zr (IV) phosphate. Talanta 71 (2) 841-847.

KAGAYA S, ARAKI Y and HASEGAWA K (2000) Flame atomic absorption spectrometric determination of lead in waste water and effluent after preconcentration using a rapid coprecipitation technique with gallium phosphate. J. Anal. Chem. 366 (8) $842-845$. 
KHALIL MI and FARAG S (1998) Utilization of some starch derivatives in heavy metal ions removal. J. Appl. Polym. Sci. 69 (1) 45-50.

KHAN AA and ALAM MM (2004) New and novel organic-inorganic type crystalline 'polypyrrolel/polyantimonic acid' composite system: preparation, characterization and analytical applications as a cation-exchange material and $\mathrm{Hg}$ (II) ion-selective membrane electrode. Anal. Chim. Acta 504 (2) 253-264.

KHANNA MN and SARIN R C (1987) J.P.S. standardization of tamarind seed polysaccharide for pharmaceutical use. Indian Drugs 24 268-269.

KOZLOWSKI CA, GIREK T, WALKOWIAK W and KOZIOL JJ (2005) Application of hydrophobic $\beta$-cyclodextrin polymer in separation of metal ions by plasticized membranes. Sep. Purif. Technol. 46 (3) 136-144.

LANG P, KAJIWARA K and BURCHARD KW (1993) Investigations on the solution architecture of carboxylated tamarind seed polysaccharide by static and dynamic light scattering. Macromolecules 26 (15) 3992-3998.

MONSER L and ADHOUM N (2002) Modified activated carbon for removal of copper, zinc, chromium and cyanide from wastewater Sep. Purif. Technol. 26 (2-3) 137-146.

MONTEAGUDO J and ORTIZ T (2002) Removal of inorganic mercury from mine wastewater by ion exchange, J. Chem. Technol. Biotechnol. 75 (9) 767-772.

NABI SA and NAUSHAD M (2008) New and novel organic-inorganic type crystalline 'polypyrrolel/polyantimonic acid composite system: characterization and analytical applications as a cationexchange material and $\mathrm{Hg}$ (II) ion-selective membrane electrode. Coll. Surf. A: Physicochem. Eng. Aspects. 316 217-225.

NENOV V and BONEV B (2010) Sorption of heavy metals by modified chelating ion exchangers. Int. J. Environ. Technol. Manage. 12 (2-4) 343-358.

OUKI SK and NEUFELD RD (1999) Use of activated carbon for the recovery of chromium from industrial wastewaters. J. Chem. Technol. Biotechnol. 70 3-8.

RADOVIC LR, SILVA IF, UME JI, MENENDEZ JA, LEON CA, LEON Y and SCARONI AW (1997) An experimental and theoretical study of the adsorption of aromatics possessing electron-withdrawing and electron-donating functional groups by chemically modified activated carbons. Carbon 35 (9) 1339-1348.
RAMOS RL, RANGEL-MENDEZ JR,MENDOZA-BARRON J, FUENTES-RUBIO, L and GUERRERO-CORONADO, RM (1997) Adsorption of cadmium from aqueous solution onto activated carbon. Water Sci. Technol. 35 (7) 205-211.

RENGARAJ S, YEON KH and MOON SH (2001) Removal of chromium from water and wastewater by ion exchange resins. J. Hazard. Mater. B. 87 273-287.

RUBIO J and TESSELE F (1997) Removal of heavy metal ions by adsorptive particulate flotation. Miner. Eng. 10 (7) 671-679.

SAHA B, IGLESIAS M, CUMMING IW and STREAT M (2000) Sorption of trace heavy metals by thiol containing chelating resins. Solvent. Extr. Ion Exch. 18 (1) 133-167.

SANTOSA J, SISWANTA D, SUDIONO S and SEHOL M (2007) Synthesis, utilization of chitin-humic acid hybrid as sorbent for Cr(III). Surface Sci. 601 (22) 5148-5154.

SARIN VK, KENT SBH and MERRIFIELD RB (1980) Properties of swollen polymer networks, solvation and swelling of peptidecontaining resins in solid-phase peptide synthesis. J. Am. Chem. Soc. 102 5463-5470.

SHIM JW, PARK SJ and RYU SK (2001) Effect of modification with $\mathrm{HNO}_{3}$ and $\mathrm{NaOH}$ by pitch- based activated carbon fibers. Carbon 39 (11) 1635-1642.

SHUKLA R and RAO GN (2002) Solvent extraction of metals with potassium-dihydro-ispyrazolyl-borate. Talanta 57 (4) 633-639.

SINGH AV, GUPTA S and GUPTA SC (1996) Synthesis of a guaransulphonic acid cation-exchanger and its application in metal ion removal from underground mine water of the Rajpura Dariba Mines, Udaipur, India. Desalination 104 (3) 235-238.

SINGH AV, SHARMA NK and RATHORE AS (2011) Synthesis, characterization and applications of new cation exchanger tamarind sulphonic acid (TSA) resin. Environ. Technol. 1 1-8.

VOGEL A (1989) Textbook of Qualitative Chemical Analysis (5 ${ }^{\text {th }}$ edn.). Longman Group, London.

WAN NAGH S, ENDUD CS and MAYANAR R (2002) Removal of copper (II) ions from aqueous solution onto chitosan and crosslinked chitosan beads. React. Funct. Polym. 50 (2) 181-190.

WONG KS, WONG KH, NG S, CHUNG WK and WONG PK (2007) Adsorption of copper ion on magnetite immobilized chitin. Water Sci. Technol. 56 (14) 135-143.

ZHOU D, ZHANG L, ZHOU J and GUO S (2004) Cellulose/chitin beads for adsorption of heavy metals in aqueous solution. Water Res. 38 (11) 2643-2650. 